\title{
The introduction of the newest biotechnologies is necessary for sustainable agricultural development and needs the sufficient investments
}

\section{Vasily NECHAEV, ${ }^{1}$ Alex GAPONENKO ${ }^{2}$}

\author{
${ }^{1}$ Russian State Agrarian University - Moscow Timiryazev Agricultural Academy \\ ${ }^{2}$ Koltzov Institute of Development Biology, Russian Academy of Sciences
}

Authors of the analytical report «World Agriculture Towards 2030/2050» made conclusion that growing global demand for food cannot be satisfied if the agricultural production in the world does not increase by $60 \%$ for the next 40 years (Alexandratos and Bruinsma, 2012). This could be achieved only by increase the plants productivity, not at the expense of expansion farms land, because to 2050 area of world lands will grow on $5 \%$. World population growth and reduction of the world area planted with wheat has alerted governments of G20, which adopted "The International Research Initiative for Wheat Improvement". Wheat biotechnology rapidly evolves throughout the world. In 2009 three major wheat exporting countries have signed the declaration to speed up the commercialization of GM-wheat. In this article we evaluated the genetic engineering achievements, and their usage for increasing profitability of wheat.

Keywords: wheat production, innovation technologies, genetic engineering, investments

\section{Introduction}

Wheat is counted among the 'big three' cereal crops, with over 600 million tons being harvested annually. For example, in 2007, the total world harvest was about $607 \mathrm{~m}$ tons compared with $652 \mathrm{~m}$ tons of rice and $785 \mathrm{~m}$ tons of maize. However, wheat is not unrivalled and in its range of cultivation, from $670 \mathrm{~N}$ in Scandinavia and Russia to $450 \mathrm{~S}$ in Argentina, including elevated regions in the tropics and sub-tropics (Feldman, 1995; FAOSTAT, 2013). It is also unrivalled in its range of diversity and the extent to which it has become embedded in the culture and even the religion of diverse societies. Wheat is a strategic product for Russia and the whole world. Currently, wheat provides $21 \%$ of all food calories in the world. For the 4.5 billion people in 94 developing countries, wheat is worth $20 \%$ of the consumption of necessary protein (Shewry, 2009). Governments in the $\mathrm{G} 20$ countries and the scientific community are concerned about population growth and decreasing the area under wheat by 3.8\% worldwide (Fig. 1). In the United States from 1993 to 2012 , the area under wheat was reduced by $25 \%$, because the common wheat is not competitive with biotech corn and soybeans. Comparing of common wheat profitability and biotech crops such as corn and soybeans, we

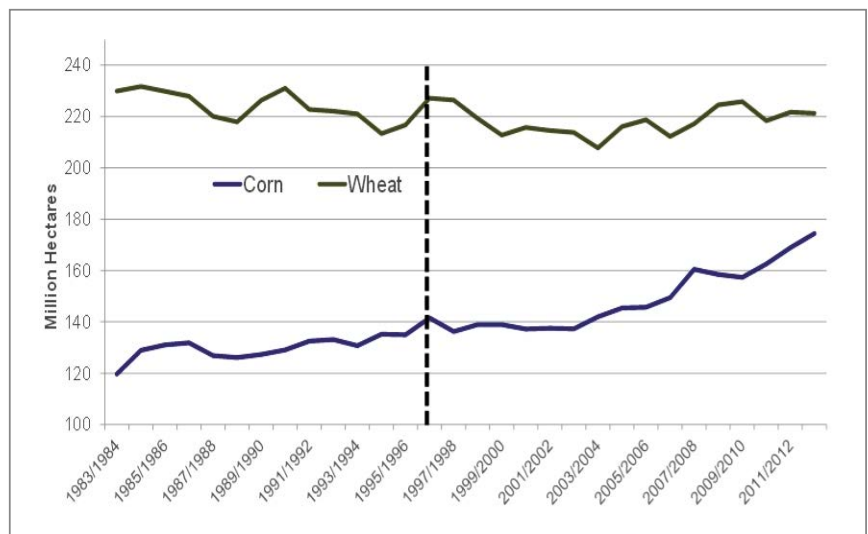

Figure 1 Hungarian TDM Organizations in 2013 Source: Schlect, 2012 must conclude that usual wheat brings in 3.4 times less income per hectare than GM-corn and 2.3 times less than the GM-soybean (Fig. 2). Biotech crops naturally displace conventional wheat creating a deficit in the production of essential goods and raise the price of bread and bakery products and pasta. The Russian President Vladimir Putin, speaking at the APEC summit, said:

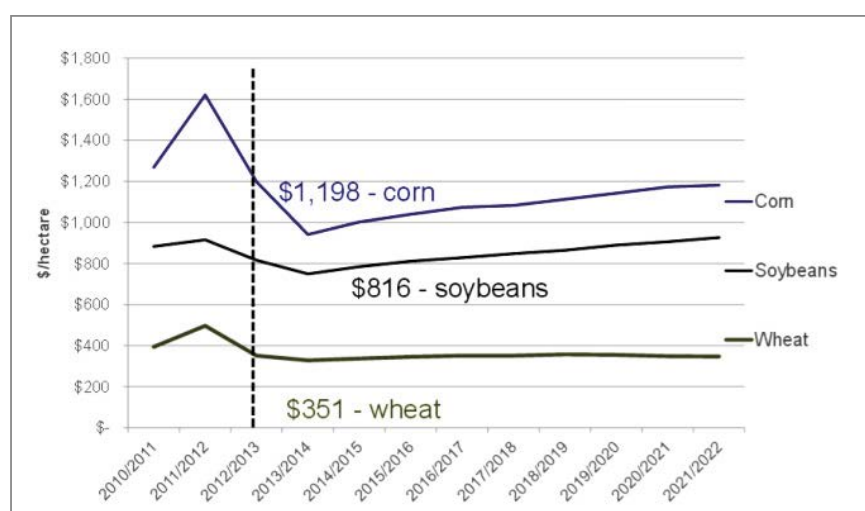

Figure 2 US National return per hectar for maior crops - corn, soybean and wheat

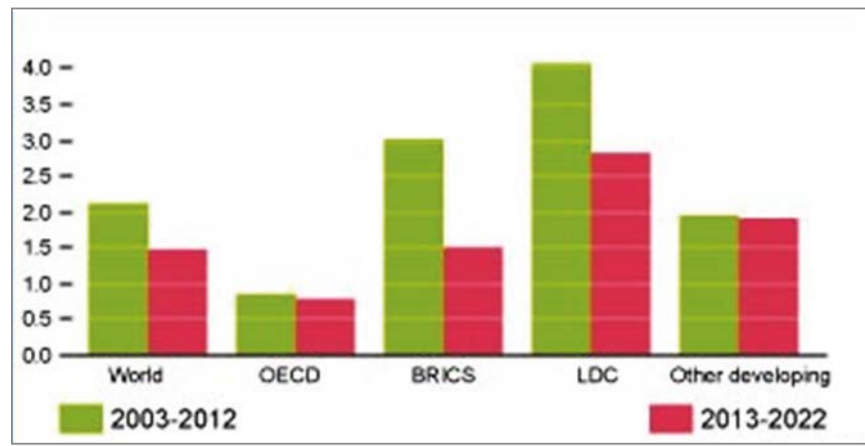

Figure 3 Net agricultural output to slow. Average annual growth rate in \% Source: OECD, FAO Agricultural Outlook 


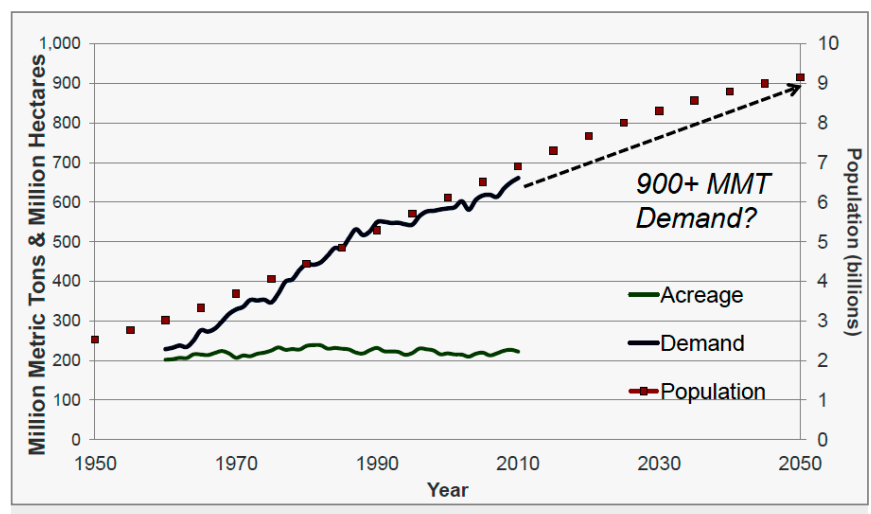

Figure 4 Future - World population, wheat acreage and wheat Consumption

Source: Schlect, 2012

„Russia in 2020 will produce up to 125 million tons of grain per year and export up to 40 million tons instead of the current 15-20 million tons" (Putin, 2012). It is time to count the profitability of wheat production in Russia and look for ways to improve the efficiency of wheat grain production.

Global agricultural production is growing slower than in previous decade. Global agricultural production for commodities covered in OECDFA0 Agricultural Outlook 2013-2022 is projected to grow at 1.5\% annually, on average, compared to $2.1 \%$ in the previous decade. This slower growth is expected to be exhibited by all crop sectors and livestock production (Fig. 3).

These trends reflect rising costs, growing resource constraints, and increasing environmental pressures, which are anticipated to inhibit supply response in virtually all regions (OECD-FAO, 2013). Predicting the future needs of the world population in wheat we have to accommodate the growth of the population and a possible increase in the production of wheat, which is still based on the available and suitable for wheat production areas. The largest reserves are primarily in the Russian Federation, the USA, Canada, Argentina, and Australia. But as we can see in Figures 1 and 2 that in the U.S. and Canada biotech crops replacing wheat and wheat production in Russia is on the edge of profitability, when watching low quality of wheat grain (Fig.4).

\section{Material and methodology}

Wheat biotechnology rapidly evolves throughout the world. In 2009 three major wheat exporting countries have signed the declaration to speed up the commercialization of GM-wheat. In this article we evaluated the genetic engineering achievements, and their usage for increasing profitability of wheat. To point at various aspects of wheat improvement and other related issues the descriptive and analytical methodological approach has been used, including both macro level and micro level factors. Official documents and guidelines of global, institutional and national relevance are have been discussed to introduce a certain framework for sustainable agriculture development, wheat improvement and latest biotechnology research and outcomes.

\section{Results and discussion}

In the last 20 years, wheat has become an orphan crop in terms of research investments compared to the most rapidly developing major cereal crop and maize. As of 2010, global investments in maize, mostly in the US and Europe, are more than four times greater than in wheat research. The public and private sectors must address the great challenges facing wheat through substantially increased investment in wheat research. During 2009-2012, the world has seen remarkable developments in wheat research, primarily on biotechnology and international attention to wheat research and it funding.

Major efforts are underway worldwide to increase wheat production by extending genetic diversity and analyzing key traits, and genomic resources can accelerate progress. But so far the very large size and polyploidy complexity of the bread wheat genome have been substantial barriers to genome analysis. International consortium has reported the sequencing of its large, 17-gigabasepair, hexaploid wheat genome using 454 pyrosequencing, and comparison of this with the sequences of diploid ancestral and progenitor genomes.

They identified between 94,000 and 96,000 genes, and assigned two-thirds to the three component genomes (A, B and D) of hexaploid wheat. High-resolution synteny maps identified many small disruptions to conserved gene order. They show that the hexaploid genome is highly dynamic, with significant loss of gene family members on polyploidization and domestication, and an abundance of gene fragments. Several classes of genes involved in energy harvesting, metabolism and growth are among expanded gene families that could be associated with crop productivity. Their analyses, coupled with the identification of extensive genetic variation, provide a resource for accelerating gene discovery and improving this major crop (Brenchley et al., 2012).

\section{The International Research initiative for Wheat Improvement (IRIWI)}

At the Meeting of G20 Agriculture ministers, Paris, 22-23 June 2011 there was decided to launch the IRIWI, bridging national research programs and the international wheat program coordinated by CIMMYT (the CGIAR's International Maize and Wheat Improvement (enter). With the application of exciting new technologies, new varieties and production technologies could raise the economic value of wheat production by 6-25 billion USD/year from 2030 onwards, based on different scenarios with partial or complete achievement of a $50 \%$ wheat yield increase, and calculated at the current wheat price. The availability of a high quality reference sequence of the wheat genome coupled with the development of efficient phenotyping methodologies for field testing will enable new genome-based breeding strategies to create robust new varieties in 15 years' time (G20 Ministerial Declaration, 2011). Ministerial declaration action plan on food price volatility and agriculture:

$\square$ Cooperate in world-wide bread and durum wheat improvement research efforts in the field of genomics, genetics and agronomy, to increase food security, wheat nutritional value and safety while taking into account societal demands for sustainable and resilient agricultural production systems.

$\square$ Provide a forum to identify synergies and encourage collaborations among major nationally, regionally and internationally (public and private) funded wheat programs with the result of maximizing opportunities for gaining added-value internationally.

$\square$ Communicate to national and international funding agencies as well as to agricultural Ministries the needs of the wheat research community of participating nations. INRA (Institute National de la Recherche Agronomique), BBSRC (Biotechnology and Biological Sciences Research Council) and (IMMYT will contribute to the coordination of activities of the International Wheat Research Coordination Committee for the 4 first years of the project. Over this initial period, sustainable funding mechanisms will be created through engagement of research and funding organizations in the public and private sector, on a voluntary basis" (G20 Ministerial Declaration, 2011).

\section{Wheat yield network communique (WYN)}

Funders and research organizations from 16 countries, met in Mexico City on November 13, 2012 to advance a Wheat Yield Network (WYN) aimed at raising 
the genetic yield potential of wheat by up to $50 \%$ over the next 20 years. The WYN would be aligned with the vision, policy and scientific activities of the IRIWI established following G20 meetings in 2011 and reaffirmed in 2012. This will need to be coupled with a willingness of funding organizations to take new and flexible approaches to supporting research, in terms of the funding models employed, the types of research included within large multinational programs, and the integration of complementary initiatives (WYNC, 2012).

\section{Presidential Commission Calls for More Agro Research Funds (USDA, USA)}

A high-level report on agriculture research funding was issued by the White House Office of Science and Technology, underscoring the importance of farming to the domestic economy and the global population. The President's Council on Advisors on Science and Technology (PCAST) issued the report, which focused on the need for agricultural preparedness and the existing U.S. research infrastructure. Noting the emerging and evolving threats to agriculture production, the paper makes the case for additional and rebalanced funding for research programs dedicated to agriculture. It also calls for an additional $\$ 700$ million in annual funding for agriculture research, which a report co-chair said is justified because agriculture research funding has been flat for decades. The report prioritizes the top seven challenges facing agriculture. Managing new pests, pathogens and invasive plants is at the top of that list, and the paper singles out Ug99 wheat stem rust as an example of an evolving and potentially devastating new pest. To capture the maximum "innovation potential" from government funding for AG research, the report urges a rebalancing of how that research is funded to focus more on competitive grants and deemphasize research that overlaps with that done in private industry. Plant research takes long-term, committed funding and special expertise, and much of the innovation available to farmers from wheat research still comes from the public system. Despite additional private money into the crop in recent years, wheat research being conducted by USDA's Agricultural Research Service (ARS) is still fundamental to wheat's viability as a U.S. crop and food source for consumers around the world (PCAST, 2012).

\section{Environmental risks affecting crops productivity}

The main risk factors for crops production, which are direct supply of food in the form of flour, edible oil, fruits and vegetables is the basis of feed for livestock and poultry are the so-called abiotic factors - extreme high and low temperatures and water deficit, which in recent years, often turning into catastrophic drought. The drought in 2009 caused billions of dollars of damages to agricultural production of the Russian Federation, the USA, Australia and some another countries wheat producers and importers. The second important groups of risks of yield decreasing are biotic factors in the form of insect pests (up to 13-25\%), pathogens (15-30\%) and weeds (20\%). All together losses caused by biotic stresses can reach $50 \%$ or even more from potential crops yield. Currently, the Russian Federation has created high productive varieties of cereals and sunflower, which by their potential productivity in environmental conditions with a huge deficit of environmental resources are unique. Winter and spring wheat in the Russia at $95-100 \%$ of the area are sown by the domestic varieties. New varieties with high yield potential, and most importantly high levels of quality grain, unfortunately, often cannot resist to both biotic and abiotic stresses. Russian local varieties of most important crops have no competitors in our environment in the world of breeding, but often need fine-tuning by genetic engineering, which observed in developed and in developing countries. High productive varieties need improvements by the introduction by genes, encoding resistance to the stresses by means of genetic engineering.

\section{Elimination risks of crop production via creation the new generation of GM-crop varieties, resistant to the biotic and abiotic stresses}

Higher production growth is expected from emerging economies which have invested in their agricultural sectors and where existing technologies offer good potential for closing the yield gap with the advanced economies, although yield/supply variability may be higher. The share of production from developing countries continues to increase over the outlook period (OECD-FA0, 2013). When we mentioned the existing technologies, we first had to go to genetic engineering, which is capable to improve the agronomic properties of plants and produce GM-crops that are resistant to various stresses. In this article we will not enter deeply into the debate about the biosafety of GM-crops and their products. But we will apply and cite to the world's most authoritative scientific journal "Nature", which published in the special issue articles dedicated to the results and the future of commercial GM-crops and genetic engineering.

30 years ago, at the symposium in Miami, USA, during one session, Jeff Schell, Robert Horch and Marie-Dell Hilton had reported on studies of Agrobacterium and its adaptation as a vector for plant transformation. It was first reports that they could place functional foreign genes into plant cells. It became clear that the progress obtained in all three independent groups working in different countries makes reality of improving crop by genetic engineering. The feat promised to launch an exciting phase in biotechnology, in which desired traits and abilities could be coaxed into plants used for food, fibers and even fuel (Chilton, 2001).

Yet so far, the technology has bestowed most of its benefits mainly for agribusiness always through crops modified to withstand weed-killing chemicals or resist insect pests. This has allowed farmers to increase yields and spray less pesticide than they might have otherwise. At best, such advances have been almost invisible to ordinary consumers. And at worst, they have helped to fuel the rage of opponents of genetic modification, who say that transgenic crops have concentrated power and profits in the hands of a few large corporations, and are a prime example of scientists meddling in nature, heedless of the dangers. But that could soon change, thanks to a whole new generation of GM crops now making their way from laboratory to market. (Editorials, GM Crops, 2013).

\section{Other next generation crops will be created using advanced genetic-manipulation techniques that allow high-precision editing of the plant's own genome}

Such approaches could reduce the need to modify commercial crops with genes imported from other species - one of the practices that most disturbs critics of genetic modification. And that, in turn, could conceivably reduce the public disquiet over GM foods. Whatever promise these crops may show in the laboratory, they will still have to demonstrate their benefits in painstaking, expensive and detailed field trials; jump through multiple regulatory hoops; and reassure an often skeptical public Nevertheless, most GM-organism researchers seem convinced that the worst of the technology's problems are over, and that its future is bright (Editorials, GM Crops, 2013).

\section{The first wave of GM crops was marketed mainly for farmers, with the goal of making their jobs easier, more productive and more profitable}

In 1996, for example, biotechnology firm Monsanto, introduced the first of its popular 'Roundup Ready' products: a soya bean equipped with a bacterial gene that allows it to tolerate a Monsanto-made glyphosate herbicide known as Roundup. This meant that farmers could kill off the majority of weeds with one herbicide rather than several, without damaging the profit the farmer. Other GM crops soon followed, including Monsanto's Bt cotton: a plant modified to produce a bacterial toxin that discourages destructive 
boll worms and cuts down on the need for pesticides. The ratio for the 4 main GM crops and conventional crops worldwide by 2012 is as follows: Soybeans $81 \%$ is $\mathrm{GM}, 81 \%$ of cotton is $\mathrm{GM}, 35 \%$ of corn is GM canola and $30 \%$ of $\mathrm{GM}$. Among the 170 million hectares planted with GM crops around the world, most have signs of resistance to herbicides and insects, and some carried both characteristic (Editorials, GM crops, 2013).

\section{The investigation: "GM crops: global socio-economic and environmental impacts 1996-2010" made by famous scientists from PG Economics Ltd, UK}

G. Brookes \& P. Barfoot is largely based on, the considerable body of peer reviewed literature available that has examined the economic and other reasons behind farm level crop biotechnology adoption, together with the environmental impacts associated with the changes (Brookes and Barfoot 2012). The material contained below in the table 1, is taken from the seventh annual report on the global economic and environmental impact of biotech crops, aims to provide insights into the reasons why so many farmers around the world have adopted crop biotechnology and continue to use it in their production systems since the technology first became available on a commercial basis since 1996. It is time to recall the old economic theories of Malthus and Karl Marx.

On the one hand we have rapid world population growth and in the coming future the inability to provide all nations the food and on the other side of the massive uptake of smaller companies by huge corporations, which take over the global seed market. There is a newest wave of globalization that threatens the nation's food security of many countries that do not possess the new technology. At first glance, the issue of food security from side of the crop production is not for Russia. But the free international market means substantial production costs for countries which have not possess new technologies. And without the new technologies our national crop production has not competitive ability with progressive world agriculture. More than half the world's population, $60 \%$, or $~ 4$ billion people live in 28 countries cultivating biotech crops. Of the 28 countries which planted biotech crops in 2012, 20 were developing and 8 were industrial countries; this compares with 19 developing and 10 industrial in 2011. Africa continued to make progress with South Africa increasing its biotech area by a record 0.6 million hectares to reach 2.9 million hectares; Sudan joined South Africa, Burkina Faso and Egypt, to bring the total number of African biotech countries to four (Editorials, GM Crops; 2013).

\section{But process of globalization coming to the every corner in the world} It was clear shown in the summary of e-mail conference carried out under Food and Agriculture Organization (FAO) supervision. From 5. 11. 2012 to 2. 12. 2012 FAO held a moderated e-mail conference on "GMOs in the pipeline: Looking to the next five years in the crop, forestry, livestock, aquaculture and agro-industry sectors in developing countries". A total of 770 people subscribed to the conference. Of the 109 messages that were posted, 36\% came from people living in Asia; $26 \%$ from Europe; $24 \%$ from North America; $10 \%$ from Latin America and the Caribbean; and $5 \%$ from Africa. The messages came from people living in 24 different countries. The greatest number were from people living in India (31 messages), followed by the United States (25); United Kingdom (8); Belgium, Brazil, the Netherlands, Peru, Spain and Switzerland (4 messages each); and Iran and Nigeria (3 messages each).

\section{Trilateral Biotech Statement (Wheat Biotechnology Commercialization Statement of Canadian, American and Australian Wheat Organizations May 14, 2009)}

In the interest of expressing support for more efficient, sustainable and profitable production of wheat around the world, the undersigned organizations have approved the following joint statement concerning commercialization of biotechnology in wheat: $\square$ One important tool to help feed the world into the future is biotechnology. Basic agronomic improvements to wheat like strengthening disease and insect resistance, enhancing wheat's use of soil nutrients and water, increasing its tolerance to weather extremes like drought and frost, are all possible with biotechnology. Another critical area for biotechnology is to improve the nutritional aspects of wheat to facilitate healthier living for people all over the world. Biotechnology is not the only answer to these questions, but it will be a significant component in solutions.

$\square$ In many of our production areas, wheat production is under pressure from competing crops which, through the application of biotechnology, have achieved higher productivity, reduced input use, and other benefits not available in wheat. As a result, the historic area of wheat production has declined in many areas and economics are driving producers away from wheat and into other crops if they have alternatives.

$\square$ Wheat yields are on a very slow growth trend in comparison with competing crops, and the longer it takes to increase the growth rate the bigger will be the hole from which the industry must climb.

$\square$ Biotechnology is a proven technique to deploy traits of interest with a high degree of precision in agricultural crops. Crops derived through biotechnology are subjected to strict regulatory scrutiny before commercialization. Over 10 years of global experience with biotechnology has demonstrated a convincing record of safety and environmental benefits as well as quality and productivity gains.

$\square$ In light of these resolutions, we will work toward the goal of synchronized commercialization of biotech traits in our wheat crops. While none of us hold a veto over the actions of others, we believe it is in all of our best interests to introduce biotech wheat varieties in a coordinated fashion to minimize market disruptions and shorten the period of adjustment. We are also committed to working with other stakeholders to address their needs and concerns as we travel the road to commercialization (Trilateral Biotech Statement, 2009).

\section{The British government supports the development of GMOs}

Environment secretary, Owen Paterson, has chosen to highlight GM technology in his first major speech to farmers. The British public should be persuaded of the benefits of genetically modified food, the environment secretary will tell the UK's farming industry, in a key signal of the government's intent to expand agricultural biotechnology and make the case for GM food in Europe. Owen Paterson, told to the Oxford Farming Conference: „We should not be afraid of making the case to the public about the potential benefits of GM beyond the food chain - for example, reducing the use of pesticides and inputs such as diesel. I believe that GM offers great opportunities but I also recognize that we owe a duty to the public to reassure them that it is a safe and beneficial innovation". He added: „As well as making the case at home, we also need to go through the rigorous processes that the EU has in place to ensure the safety of GM crops" (British Government, 2013).

\section{Second generation of GM technology to emulate natural plant defense mechanisms Rothamsted Wheat Trial, Great Britain}

Aphids (also known as greenfly and blackfly) are unwelcome visitors that suck sap from plants. They cause significant damage to agriculture and reduce farmers' yields by damaging crops and spreading plant diseases. Wheat is the most important UK crop with an annual value of about $£ 1.2$ billion. Currently a large proportion of UK wheat is treated with broad spectrum chemical insecticides to control cereal aphids that reduce yields by sucking sap from plants and by transmitting barley yellow dwarf virus. Unfortunately, repeated use of 
insecticides often leads to resistant aphids and kills other non-target insect species including the natural enemies of aphids, which could have a further impact on biodiversity. Scientists at Rothamsted, funded by the UK Government through the Biotechnology and Biological Science Research (BBSRC) have been seeking novel ecological solutions to overcome this problem in wheat. One approach has been to use an odour, or alarm pheromone, which aphids produce to alert one another to danger. This odour, $(E)-\beta$-farnesene, is also produced by some plants as a natural defense mechanism and not only repels aphids but also attracts the natural enemies of aphids, e.g. ladybirds. Scientists are using biotechnological tools to genetically engineer a wheat plant which produces high levels of this aphid repelling odour, which could help promote sustainable and environmentally friendly agriculture. It forms part of a wider scientific strategy for Rothamsted research to meet the challenge of increasing food and energy production in a more environmentally sustainable way. The new GM project will test if it is possible to deliver semi chemicals from crops themselves instead of having to grow additional companion crops (Rothamsted, 2012).

\section{A new generation of GM crops resistant to abiotic stresses such as drought, reduced temperature and new pest resistance is coming}

We can cite as an example actions of Australian Plant Functional Genomics Center (University of Adelaide, Australia), where in the last few years about 50 genes of transcription factors have been allocated such as DREB, NAC and other, each of which regulate the action of dozens of genes involved in the response of plants to water deficit and extreme temperatures (APFGC, 2010). Monsanto Company created collection of 6800 samples of DNA encoding Bt genes determining resistance to insects of different families. Total in the world about $300 \mathrm{Bt}$ genes have been patented. Different forms of genes EPSPS, determining resistance to the most popular herbicide Roundup (glyphosate), isolated and patented by Monsanto. The term of the patent of the gene statute of limitations has expired due of the date of application. Total in world practice identified several hundred genes, some of them were successfully introduced into the genomes of various crop plants. In addition, we mention a few publications on the successful use of transcription factors to create a stress-resistant plants cereals (Xingnan et al., 2009; Gang-Ping et al., 2011; Bahieldina et al., 2005).

\section{Efficient systems of genetic transformation of wheat for creation and commercialization of a new generation of varieties that are resistant to stresses}

Numerous methods have been used to integrate cloned DNA sequences into wheat cells to produce fertile, adult transgenic wheat lines but two predominate now: T-DNA transfer via Agrobacterium tumefaciens and the direct insertion of naked DNA via particle bombardment. The original particle bombardment device employed a gunpowder charge to accelerate the macrocarrier and was used by Sanford et al. (1987) to deliver tungsten particles into epidermal cells of maize. Sanford also coined the phrase 'biolistic' to describe this 'biological ballistic' protocol. Fertile transgenic wheat plants were first generated using an improved version of the biolistic device (the DuPont PDS 1000 apparatus, Bio-Rad, Hercules, (alifornia, USA), which used high-pressure helium to drive fine metal microcarriers coated with DNA into specific callus types from long-term cultures (Vasil et al., 1992). We have been working on wheat regeneration and transformation since 1984 (Gaponenko et al., 1984, 1985; Fadeev and Gaponenko, 2004; Fadeev et al., $2006,2009)$. Our first goal was the development of the efficient wheat genetic transformation system for the creation of the transgenic wheat resistant to the Sunn pest (Eurygaster integriceps Puton). In the beginning we have used the biolistic device made in the John Finer Laboratory, Wooster, Ohio State university, USA (Finer et al., 1992). Transformation of wheat through Agrobacterium had been attempted since 1988, but stable transformation became possible through a reliable and relatively efficient transformation procedure and construction of a new plasmid vector (Cheng et al., 1997) with stable integration, expression and inheritance of transgene to next generation. Further improvement in the plasmid vector and wheat transformation procedure increased the transformation efficiency. Several investigators obtained subsequent successful transformation of wheat through Agrobacterium with more than 4\% transformation efficiency (Chen et al., 2003; Ming, 2003; Liping et al., 2009).

Afew domesticanalysises of the prospects for increasing grain production in Russia provides an analysis of the current state of the industry; evaluation of potential grain production; identified obstacles to the implementation of the existing building; analyze the international experience of public support for grain producers, and finally makes recommendations for adjusting the Russian state agricultural policy (Alimov, 2012; BusinesStatht,2012; Skurihin, 2012). But virtually no attention has been paid from the scientific innovative components for increase yield and profitability of wheat. Cost of production of grain in Russia is much higher than in developed countries. The main reasons are - low productivity and wheat yield per hectare. Both parameters are lower than in foreign countries with developed agriculture. The yields we are lagging behind the U.S. and Canada by $15-25 \%$, and the performance of our backlog is $34-44 \%$. Low levels of productivity and performance associated with low use of fertilizers, as well as extremely low funding for the breeding and seed and basic scientific research in plant biotechnology.Increased production of high-quality grain is the basis for the development of food processing industry and for the growing of wheat exports. Grain quality in key areas of the Russian Federation, producing wheat, has been declining because of the defeat of grains of wheat bug Sunn (Eurygaster integriceps Puton), destroying proteins - glutenins, determining the baking quality of the grain. Since 2009, importers of Russian wheat imposed new restrictions - food wheat is wheat with zero defeat grain by Sunn pest. According to the director of the Institute for Agricultural Market Dmitry Rylko economic loss of market participants wheat from the defeat Sunn pest can make up to $\$ 500$ million a year. On the development of innovative biotechnology project: «Creating a new generation of wheat varieties that are resistant to the economically significant pest of wheat - the bug Sunn (Eurygaster integriceps Puton), by means of biotechnology methods to improve the quality of the grain of wheat," the group of A.K.Gaponenko successfully operating for over 8 years.

\section{Russian government has adopted the "Road Map For Genetic Engineering"}

The "roadmap" is conceptually linked to the Comprehensive Program of biotechnology in the Russian Federation for the period up to 2020 approved by the Prime Minister of the Russian Federation (no.1853, p. P8 on April 24, 2012). In this Program, in sector of "Agricultural biotechnology" indicated that most priority is development of new varieties of agricultural plants using post-genomic methods and biotechnology. Currently, in the Russian Federation almost are not creating varieties and hybrids of the new generation, that are resistant to drought, disease, herbicides, pests and adverse environmental conditions, using genetic engineering techniques. Without biotechnology innovations agricultural production Russia will still are expensive and lose in competition with foreign countries. In the Road Map for Genetic Engineering listed the following activities:

$\square$ Genetic engineering: Approval of the procedure of state registration genetically modified organisms, intended for release into the environment, and products obtained by using such organism or organisms such decision of the Government of the Russian Federation.

$\square$ Agro-food biotechnology (agriculture and food processing): (reating the Functional Genomics Center of agricultural plants, animals and aquaculture. 


\section{Conclusion}

The solution of the important economic problems of the Russian and any country which involved in producing wheat grain agricultural sector like: "Increasing profitability and quality of wheat grain production by means scientific innovation" has become a very real possibility. First new varieties generation could be expected during next 5 years. These will be varieties with high quality soft and durum wheat for bread and macaroni production, resistant to herbicides and main pest. They could be created on the base of best high productive local varieties. Second generation of GM wheat will be developed during next 10 years: wheat varieties drought tolerant, with improved yield these varieties must be herbicide and main pest resistant plus, with better nitrogen utilization and disease control.

\section{Reference}

ALEXANDRATOS NIKOS - JELLE BRUINSMA. 2012. World Agriculture Towards 2030/2050: The 2012 revision ESA E Working Paper No.12-03, [online] Retrieved [2013-09-19] from: http://www.fao.org/economic/esa/esag/en/

ALIMOV, K. G. 2012. Innovative efficiency of grain production. [online] Retrieved [2013-0919] from: http://www.agroyug.ru/page/item/_id-5186/

APEC Summit in Vladivostoc. 2012. [online] Retrieved [2013-09-19] from: http://en.rian. ru/business/20120907/175823130.html

APFGC (AUSTRALIAN PLANT FUNCTIONAL GENOMICS CENTER). 2010. Annual report[online] Retrieved [2013-09-19] from: http://www.acpfg.com.au/uploads/documents/ publications/ACPFG\%20Annual\%20report\%202010\%20volume\%201\%20final.pdf

BAHIELDINA, AHMED et al. 2005. Field evaluation of transgenic wheat plants stably expressing the HVA1 gene for drought tolerance, Physiologia Plantarum 123: 421427. doi: 10.1111

BRITISH GOVERNMENT SUPPORTS THE DEVELOPMENT OF GMOs. 2013. [online] Retrieved [2013-09-19] from: http://www.bbc.co.uk/news/uk-politics-20664016; http:// www.bbc.co.uk/news/science-environment-22967571

BUSINESSTATHTTP. 2012. Analysis of the wheat market in Russia in 2007-2011, the forecast for 2012-2016. [online] Retrieved [2013-09-19] from: http://www.marketing.rbc.ru/ research/562949983364619.shtml

BROOKES GRAHAM \& PETER BARF00T. 2012. PG Economics Ltd, UK, GM crops: global socioeconomic and environmental impacts 1996-2010, Dorchester, UK. [online] Retrieved [2013-09-19] from:www.pgeconomics.co.uk/pdf/2012globalimpactstudyfinal.pdf

CHEN G. et al. 2003. Agrobacterium-mediated large-scale transformation of wheat (Triticum aestivum L.) using glyphosate selection, Plant Cell Rep 21:1010-1019.

CHILTON MARY-DELL. 2001. Agrobacterium. A Memoir Plant Physiology, vol. 125, pp. 9-14

CLIVE JAMES. 2012. [online] Retrieved [2013-09-19] from: http://www.isaaa.org/ resources/publications/briefs/44/highlights/

EDITORIALS GM CROPS. 2013. Promise \& Reality. Nature special issue nature.com/gmcrops, 2 May 2013, vol., 497, Nature, 5 [online] Retrieved [2013-09-19] from: http://www. nature.com/news/gm-crops-a-story-in-numbers-1.12893; http://www.nature.com/ polopoly_ff/1.12893!/menu/main/topColumns/topLeftColumn/pdf/497220a.pdf

ETIENNE PAUX et al. 2008. A Physical Map of the 1-Gigabase Bread Wheat Chromosome 3B, Science, October 2008, vol. 322, no. 5898, pp. 101-104.

FADEEV, V.S. - BLINKOVA, O.V. - GAPONENKO, A. K. 2006. Optimization of biological and physical parameters for biolistic genetic transformation of common wheat (Triticum aestivum L.) using a particle inflow gun. In: Russian Journal Of Genetics, vol. 42, 2006, no. 4. p. 402-411.

FADEEV, V. S. - GAPONENKO, A. K. Development of the efficient wheat genetic transformation system for the creation of the transgenic wheat resistant to the sunn pest (Eurygaster integriceps Puton) In: "Sunn Pest Management A Decade of Progress 1994-2004". Published by Arab Society for Plant Protection 2007, pp. 381-389.

FAOSTAT. 2009. Data [online] Retrieved [2013-09-19] from:http://faostat.fao.org/

FELDMAN, M. 1995. Wheats. In: Smartt J, Simmonds NW, eds. Evolution of crop plants. Harlow, UK: Longman Scientific and Technical, p. 185-192.

FINER, J. J. et al. 1992. Development of the particle inflow gun for DNA delivery to plant cells. In: Plant Cell Reports, no. 11, p. 232-238.

GANG-PING XUEA et al. 2011. Overexpression of TaNAC69 Leads to Enhanced Transcript Levels of Stress, CSIRO Plant Industry, BSES Limited, Australia. In: Mol Plant, vol. 4, 2011, no. 4, p. 697-712.

GAPONENKO A. K. et al. 1984. In vitro regeneration of Triticum aestivum wheat plants. In: Proceedings Of The Ussr Academy Of Sciences, vol. 278, 1984, no. 5, p. 1231-1235.
GAPONENKO, A. K. et al. 1985. Production of somaclonal lines in cereals (Triticum aestivum L, Hordeum vulgare L). In: Proceedings Of The Ussr Academy Of Sciences, vol. 283, 1985 , no. 6, p. 1471-1475.

G20 Ministerial Declaration. 2011. Action Plan on Food Price Volatility and Agriculture International Research Initiative for Wheat Improvement (IRIWI) [online] Retrieved [2013-09-19] from:http://www.wheatinitiative.org/sites/default/files/docs/g20ministerial-declaration-june-2011.pdf

ISB (Information system for the biotechnology). 2013. [online] Retrieved [2013-09-19] from: http://www.isb.vt.edu/release-summary-data.aspx

LIPING DING et al. 2009. Optimization of Agrobacterium-mediated transformation conditions in mature embryos of elite wheat Mol Biol Rep. 2009, no. 36, p. 29-36.

MING CHENG et al. 2003. Desiccation of plant tissues post-agrobacterium infection enhances $t$-dna delivery and increases stable transformation efficiency in wheat. In Vitro Cell. Dev. Biol. Plant, 2003, no. 39, p. 595-604.

OFFICE of Science and Technology Policy (OSTP). 2013. [online] Retrieved [2013-09-19] from: http://www.whitehouse.gov/sites/default/files/microsites/ostp/pcast_ag_ release_20121207.pdf

PCAST (Presidential Commission Calls for More ag Research Funds). 2012. [online] Retrieved [2013-09-19] from:http://www.wheatworld.org/news-events/2012/12/ presidential-science-commission-calls-for-more-ag-research-funds/

RACHEL BRENCHLEYET et al. 2012. Analysis of the bread wheat genome using wholegenome shotgun sequencing, vol. 491, 2012, NATURE, p. 705-710.

RAZZAQ ABDULET et al. 2010. Genetic Transformation of Wheat (Triticum aestivum L): A Review Triticeae Genomics and Genetics, TGG, vol. 1, 2010, no. 2.

REPORT ON PROSPECTS FOR INCREASING GRAIN PRODUCTION IN RUSSIA. 2010. [online] Retrieved [2013-09-19] from: http://www.rosagromash.ru/attachments/article.pdf

ROTHAMSTED WHEAT TRIAL. 2012. Second generation GM technology to emulate natural plant defense mechanisms. [online] Retrieved [2013-09-19] from: http://www. rothamsted.ac.uk/Content.php?Section=AphidWheat

RUANE, J. 2013. An FA0 e-mail conference on GMOs in the pipeline in developing countries: The moderator's summary. FA0. [online] Retrieved [2013-09-19] from: http://www. fao.org/biotech/biotech-forum/

SANFORD, J. C. et al. Delivery of substances into cells and tissues using a particle bombardment process. In: Journal of Particulate Science and Technology, 1987, no. 5, pp. 27-37

SCHLECHT SHANNON. 2011. Developments in Biotechnology in the U.S. Wheat Sector 2011 HGCA Grain Market Outlook Conference [online] Retrieved [2013-09-19] from: http:// www.uswheat.org/meetingsEvents.nsf/Schlecht.pdf

SKURIHIN, P. 2012. Prospects for grain production in Russia up to 2020. Statement by the President of the National Union of Grain Producers Paul Skurikhina on Grain Forum Siberia. August 2, 2012, Novosibirsk, Russia [online] Retrieved [2013-09-19] from: http://nszr.ru/events/010/1085/

SHEWRY, P. R - JONES, H. D. 2009. Transgenic wheat: where do we stand after the first 12 years? In: Journal of Experimental Botany, vol. 60, 2009, no. 6, pp. 1537-1553

TRILATERAL BIOTECH STATEMENT. 2009. Wheat Biotechnology Commercialization Statement of Canadian, American and Australian Wheat Organizations, [online] Retrieved [2013-09-19] from: http://www.pgaofwa.org.au/system/press_release/ file/0000/0061/FINAL_Trilateral_Biotech_Statement.pdf

HU, T. - et al. 2003. Agrobacterium-mediated large-scale transformation of wheat (Triticum aestivum L.) using glyphosate selection. In: Plant Cell Rep, 2003, no. 21, p. 1010-1019.

VASIL, I. et al. 1992. Herbicide resistant fertile transgenic wheat plants obtained by microprojectile bombardment of regenerable embrypgenic via particle bombardment. In: J. Exp Bot., vol. 52, 1992, no. 357, p. 865-874.

WHEAT WORLD INITIATIVE. 2011. Document submitted to the G20 Agricultural Ministers, [online] Retrieved [2013-09-19] from: http://www.wheatinitiative.org/sites/ default/files/docs/g20-proposal.pdf

WHEAT YIELD NETWORK COMMUNIQUE. 2012. [online] Retrieved [2013-09-19] from: http://www.foodsecurity.ac.uk/assets/pdfs/wheat-yield-network.pdf

XINGNAN ZHENG et al. 2009. Overexpression of a NAC transcription factor enhances rice drought and salt tolerance Bioch and Bioph Res Com 379, 2009, p. 985-989.

\section{Contact address:}

Vasily I. Nechaev, Degree: Dr. Sciences, Ph.D., Professor of Economics, Rector of Russian State Agrarian University - Moscow Timiryazev Agricultural Academy, 127550, 49 Timirjazevskaja Street, Moscow, Russian Federation Phone: 8 (499) 97634 90, Fax: 8 (499) 97604 28, e-mail: nechaev@timacad.ru 